\title{
KOMPETISI JENIS DAN KERAPATAN GULMA TERHADAP PERTUMBUHAN DAN PRODUKSI KACANG TANAH (Arachis hypogaea L.) VARIETAS HYPOMA 2
}

\author{
Eka Erliyana, Dad R.J. Sembodo \& Setyo Dwi Utomo \\ Jurusan Agroteknologi Fakultas Pertanian Universitas Lampung \\ J1. Prof. Soemantri Brojonegoro, No 1 Bandar Lampung 35145 \\ Email: Eka_ven01@yahoo.com
}

\begin{abstract}
ABSTRAK
Kacang tanah merupakan tanaman kacang-kacangan yang permintaannya menduduki urutan kedua setelah kedelai. Namun, produktivitas kacang tanah yang dihasilkan Indonesia masih rendah. Salah satu faktor penyebab rendahnya produksi tanaman kacang tanah yaitu keberadaan gulma. Gulma dalam budidaya tanaman kacang tanah memiliki daya saing yang bersifat merugikan bagi pertumbuhan dan produksi kacang tanah. Tingginya penurunan hasil terhadap produksi kacang tanah dapat dipengaruhi oleh jenis dan kerapatan gulma. Penelitian ini disusun untuk mengetahui pengaruh jenis gulma terhadap pertumbuhan dan produksi tanaman kacang tanah varietas Hypoma 2, pengaruh kerapatan gulma terhadap pertumbuhan dan produksi tanaman kacang tanah varietas Hypoma 2, dan ada atau tidak adanya interaksi antara jenis dan kerapatan gulma dalam mempengaruhi pertumbuhan dan produksi kacang tanah varietas Hypoma 2. Penelitian dilaksanakan di Lampung Selatan dan Laboratorium Gulma Universitas Lampung dari bulan Januari-Mei 2015. Perlakuan ini disusun secara faktorial dalam Rancangan Petak Berjalur (Strip Plot Design) dengan 3 kali ulangan. Faktor pertama adalah tiga jenis gulma yaitu Asystasia gangetica, Cyperus rotundus, dan Rottboellia exaltata dan faktor kedua adalah kerapatan gulma yaitu 0, 10, 20, 40, dan 80 gulma $/ \mathrm{m}^{2}$. Data dianalisis dengan analisis ragam, bila terdapat perbedaan dilanjutkan dengan uji BNT pada taraf $5 \%$. Hasil penelitian menunjukkan bahwa jenis dan kerapatan gulma tidak mempengaruhi pertumbuhan dan produksi kacang tanah dan terdapat interaksi antara jenis dan kerapatan gulma dalam mempengaruhi tinggi tanaman kacang tanah, bobot 100 butir kacang tanah, dan bobot polong kering per petak.
\end{abstract}

Kata kunci: gulma, kacang tanah, kerapatan, persaingan.

\section{PENDAHULUAN}

Kacang tanah merupakan tanaman kacangkacangan yang permintaannya menduduki urutan kedua setelah kedelai. Kehadiran varietas Hypoma 2 sebagai alternatif petani dalam memilih benih unggul kacang tanah. Keunggulan kacang tanah varietas Hypoma 2 meliputi: potensi hasil mencapai 3,50 ha ${ }^{-1}$, toleran kekeringan pada fase generatif, tahan penyakit bercak dan karat daun, jumlah polong banyak, dan ukuran biji besar (Balai Penelitian Tanaman Kacang dan Umbi, 2013). Adanya pertambahan penduduk dan berkembangnya industri pengolahan makanan yang berasal dari kacang tanah di Indonesia, menyebabkan makin tingginya permintaan kacang tanah. Permintaan kacang tanah tahun 2011-2013 berturut-turut sebesar 769, 895, dan 912 ha $^{-1}$ (Direktorat Budidaya Aneka Kacang dan Umbi, 2013).

Produktivitas yang rendah dapat disebabkan oleh teknik budidaya yang tidak baik, berkaitan dengan pengendalian gulma. Gulma dalam budidaya tanaman kacang tanah memiliki daya saing yang bersifat merugikan bagi pertumbuhan dan produksi tanaman kacang tanah. Kerugian yang ditimbulkan akibat gulma di pertanaman kacang tanah dapat mencapai 50\% (Moenandir, 1993). Tingkat kompetisi ini berkaitan dengan sifat gulma dan kerapatan gulma. Sifat pertumbuhan gulma yang berbeda akan menentukan daya saing gulma tersebut terhadap suatu tanaman, begitu pula dengan kerapatan gulma. Semakin tinggi kerapatan gulma maka akan semakin besar pula penekananya terhadap produksi tanaman kacang tanah.

Menurut Sembodo (2010), periode kritis tanaman yang sangat peka terhadap persaingan gulma yaitu ketika umur tanaman kacang tanah 6 minggu setelah tanam (MST). Periode kritis untuk pengendalian gulma merupakan komponen penting dalam strategi manajemen gulma terpadu yang memberikan pengetahuan bagi petani kapan saatnya untuk mengendalikan gulma yang dapat merugikan hasil tanaman (Swanton dan Weise, 1991 
dalam Knezevic, dkk., 2002). Kerugian yang ditimbulkan akibat gulma berupa penurunan produksi dari beberapa tanaman adalah sebagai berikut: padi $10,8 \%$; sorgum $17,8 \%$; jagung $13 \%$; tebu $15,7 \%$; cokelat $11,9 \%$; kedelai $13,5 \%$ dan kacang tanah 11,8\% (Rogomulyo, 2005). Untuk mencegah kehilangan hasil kacang tanah akibat kompetisi dengan gulma, maka perlu diketahui saat yang tepat untuk melakukan pengendalian.

Penelitian ini bertujuan untuk mengetahui pengaruh jenis gulma terhadap pertumbuhan dan produksi tanaman kacang tanah varietas Hypoma 2, pengaruh kerapatan gulma terhadap pertumbuhan dan produksi tanaman kacang tanah varietas Hypoma 2, dan ada atau tidak adanya interaksi antara jenis dan kerapatan gulma dalam mempengaruhi pertumbuhan dan produksi kacang tanah varietas Hypoma 2 .

\section{BAHAN DAN METODE}

Penelitian dilakukan di kebun Hajimena, Kecamatan Natar, Kabupaten Lampung Selatan dan Laboratorium Gulma Universitas Lampung dari bulan Januari-Mei 2015.Bahan dan alat yang digunakan yaitu benih kacang tanah varietas Hypoma 2, bibit gulma Asystasia gangetica, Cyperus rotundus, Rottboellia exaltata, kapur $41,4 \mathrm{~kg} / 90 \mathrm{~m}^{2}$, pupuk Phonska $300 \mathrm{~kg} /$ ha dan pupuk Urea $100 \mathrm{~kg} /$ ha sedangkan alatnya yaitu koret dan mistar.

Penelitian disusun secara faktorial dalam Rancangan Petak Berjalur (Strip Plot Design) dengan 3 kali ulangan. Faktor pertama adalah tiga jenis gulma yaitu $A$. gangetica, $C$. rotundus, dan $R$. exaltata. Faktor kedua adalah kerapatan gulma yaitu 0, 10, 20, 40, dan 80 gulma $/ \mathrm{m}^{2}$ dengan masing-masing jarak 40 $\mathrm{cm} \times 25 \mathrm{~cm} ; 25 \mathrm{~cm} \times 20 \mathrm{~cm} ; 25 \mathrm{~cm}$ x $10 \mathrm{~cm}$; dan $12,5 \mathrm{x}$ $10 \mathrm{~cm}$. Homogenitas data diuji dengan uji Barlett dan aditivitas diuji dengan uji Turkey. Bila asumsi terpenuhi, data dianalisis dan dilanjutkan dengan uji BNT pada taraf $5 \%$.

Lahan penelitian yang digunakan seluas $135 \mathrm{~m}^{2}$ disiapkan dengan cara dibajak dan dicangkul. Selanjutnya, petak-petak percobaan dibuat sebanyak 45 petak perlakuan, dengan ukuran setiap petak $1 \mathrm{~m}$ x $2 \mathrm{~m}$ dan jarak antar petak $0,5 \mathrm{~m}$. Kacang tanah ditanam dengan ditugal sebanyak 1 benih per lubang dengan jarak tanam $40 \times 15 \mathrm{~cm}^{2}$, setelah 1 MST dilakukan penanaman gulma. Penanaman gulma pada penelitian ini dengan cara transplanting bibit gulma ke petak yang sudah disiapkan. Gulma yang dipindahkan ke lahan ketika gulma tersebut memiliki 3-4 helai daun atau dengan ketinggian yang seragam, hal ini bertujuan agar pertumbuhan tanaman dan gulma seragam.
Pemeliharaan tanaman kacang tanah meliputi: Pemupukan pada kacang tanah menggunakan pupuk Phonska dan Urea, seluruhnya diberikan pada umur tanaman 7 hst. Dosis pupuk yang digunakan yaitu Phonska $300 \mathrm{~kg} / \mathrm{ha}$ dan Urea $100 \mathrm{~kg} / \mathrm{ha}$ dengan cara ditugal.

Penyiraman disesuaikan dengan kebutuhan tanaman. Pemurnian gulma dilakukan secara mekanis yang dilakukan setiap hari dengan cara mencabut gulmagulma lain yang berada di petak selain gulma yang ditanam yaitu: A. gangetica, C. rotundus, dan $R$. exaltata. Pengendalian hama dan penyakit dilakukan dengan aplikasi pestisida apabila serangan hama/ penyakit cukup tinggi pada tanaman kacang tanah. Aplikasi pestisida ini dilakukan setiap 1 minggu sekali.

Variabel pengamatan meliputi: Bobot kering gulma diamati saat fase vegetatif maksimum tanaman kacang tanah (6 MST) yang dilakukan dengan menggunakan kuadran berukuran $0,5 \times 0,5 \mathrm{~m}^{2}$, kemudian dikeringkan menggunakan oven pada suhu $80^{\circ} \mathrm{C}$ selama $2 \times 24$ jam sampai bobotnya konstan kemudian ditimbang.

Tinggi tanaman kacang tanah diukur mulai dari permukaan tanah sampai titik tumbuh tanaman. Bobot 100 butir pada kadar air 14\% dilakukan dengan menghitung biji kacang tanah hingga 100, kemudian ditimbang bobotnya dengan menggunakan timbangan elektrik setelah itu dihitung kadar air biji kacang tanah tersebut.

$$
\text { KA } 14=\frac{100-\text { KA terukur }}{100-14} \times \text { Bobot } 100 \text { butir }
$$

Bobot polong kering per petak 1,5 $\mathrm{m}^{2}$ diamati dengan menimbang bobot polong kering yang sudah dijemur selama 1 minggu.

\section{HASIL DAN PEMBAHASAN}

Terdapat interaksi antara jenis dan kerapatan gulma dalam mempengaruhi bobot kering gulma. Pada kerapatan 10 sampai 80 gulma $/ \mathrm{m}^{2}$, bobot kering gulma $R$. exaltata lebih tinggi daripada gulma $A$. gangetica dan C. rotundus (Gambar 1). Menurut Reeder, dkk. (1996), R. exaltata temasuk tumbuhan C4 yang mampu beradaptasi dengan kondisi kering dan basah, lebih tinggi, tegak, dan bercabang sehingga sarana tumbuh seperti cahaya, air, dan unsur hara akan lebih banyak dimanfaatkan oleh $R$. exaltata. Penelitian ini sejalan dengan pendapat Suryadi, dkk. (2013), tingginya bobot kering gulma dipengaruhi oleh intensitas cahaya yang diterima gulma lebih tinggi akibatnya proses fotosintesis 
akan berjalan lebih cepat sehingga sarana tumbuh dan unsur hara yang dimanfaatkan $R$. exaltata lebih tinggi.

Bobot kering gulma $A$. gangetica dan $C$. rotundus sama pada semua kerapatan. Bobot kering kedua gulma tersebut pada kerapatan 10 gulma $/ \mathrm{m}^{2}$ tidak berbeda dengan 20 gulma $/ \mathrm{m}^{2}$, begitupun dengan kerapatan 20 dan 40 gulma $/ \mathrm{m}^{2}$, dan kerapatan 40 dengan 80 gulma $/ \mathrm{m}^{2}$. Bobot kering kedua gulma tersebut pada kerapatan 80 gulma $/ \mathrm{m}^{2}$ lebih tinggi daripada kerapatan 10 dan 20 gulma $/ \mathrm{m}^{2}$. Bobot kering gulma $R$. exaltata tidak terdapat perbedaan pada kerapatan 10 dan 20 gulma/ $\mathrm{m}^{2}$, begitupun dengan kerapatan 20 dan 40 gulma/ $\mathrm{m}^{2}$ sedangkan kerapatan 80 gulma $/ \mathrm{m}^{2}$ paling tinggi daripada kerapatan lainnya (Gambar 2). Kerapatan gulma yang semakin tinggi akan diikuti dengan bobot kering gulma yang tinggi, sehingga sarana tumbuh yang dipersiapkan untuk tanaman sebagian besar dimanfaatkan oleh gulma tersebut (Arnon, 1975).

Terdapat interaksi antara jenis dan kerapatan gulma dalam mempengaruhi tinggi tanaman kacang tanah. Pada kerapatan sama tinggi tanaman kacang tanah yang berkompetisi dengan ketiga jenis gulma tidak berbeda (Gambar 3). Pada perlakuan gulma $C$. rotundus, tinggi tanaman pada kerapatan 0 tidak berbeda dengan kerapatan 10 gulma $/ \mathrm{m}^{2}$, begitupun dengan kerapatan 10, 20, 40, dan 80 gulma $/ \mathrm{m}^{2}$. Sebaliknya pada perlakuan gulma $A$. gangetica dan $R$. exaltata, tidak mempengaruhi tinggi tanaman kacang tanah (Gambar 4). Pada kerapatan 20 sampai 80 gulma $/ \mathrm{m}^{2}$ tanaman yang berkompetisi dengan $C$. rotundus mengakibatkan tinggi tanaman tertekan sebesar $10-11 \%$. Menurut penelitian Pranesti, dkk. (2014), C. rotundus memiliki

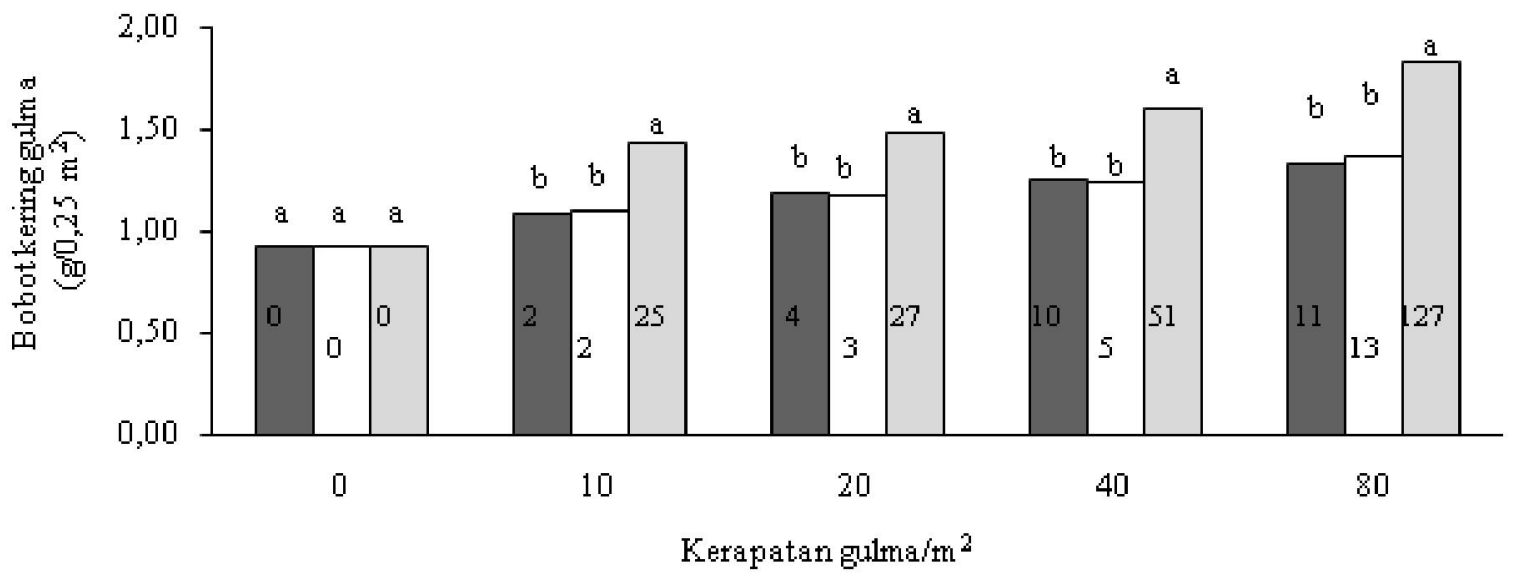

Gambar 1. Pengaruh jenis dan kerapatan gulma terhadap bobot kering gulma (Transformasi $\sqrt{ } \sqrt{ }(x+0,5))$, $\square=$ A. gangetica, $\square=C$. rotundus, $\square=R$. exaltata, BNT $(0,05)=0,21$.

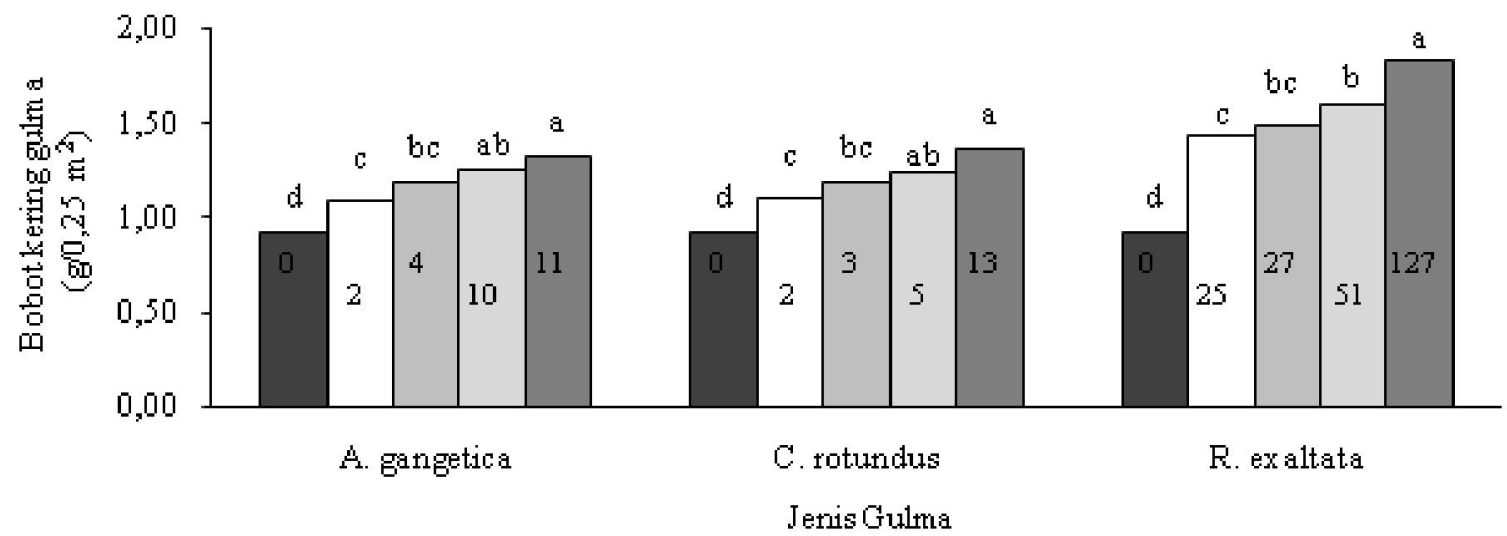

Gambar 2. Pengaruh jenis dan kerapatan gulma terhadap bobot kering gulma (Transformasi $\sqrt{ } \sqrt{ }(x+0,5))$, $\square=0$ gulma $/ \mathrm{m}^{2}, \square=10$ gulma $/ \mathrm{m}^{2}, \square=20$ gulma $/ \mathrm{m}^{2}, \square=40$ gulma $/ \mathrm{m}^{2}, \square=80$ gulma $/ \mathrm{m}^{2}$, BNT $(0,05)=0,13$. 


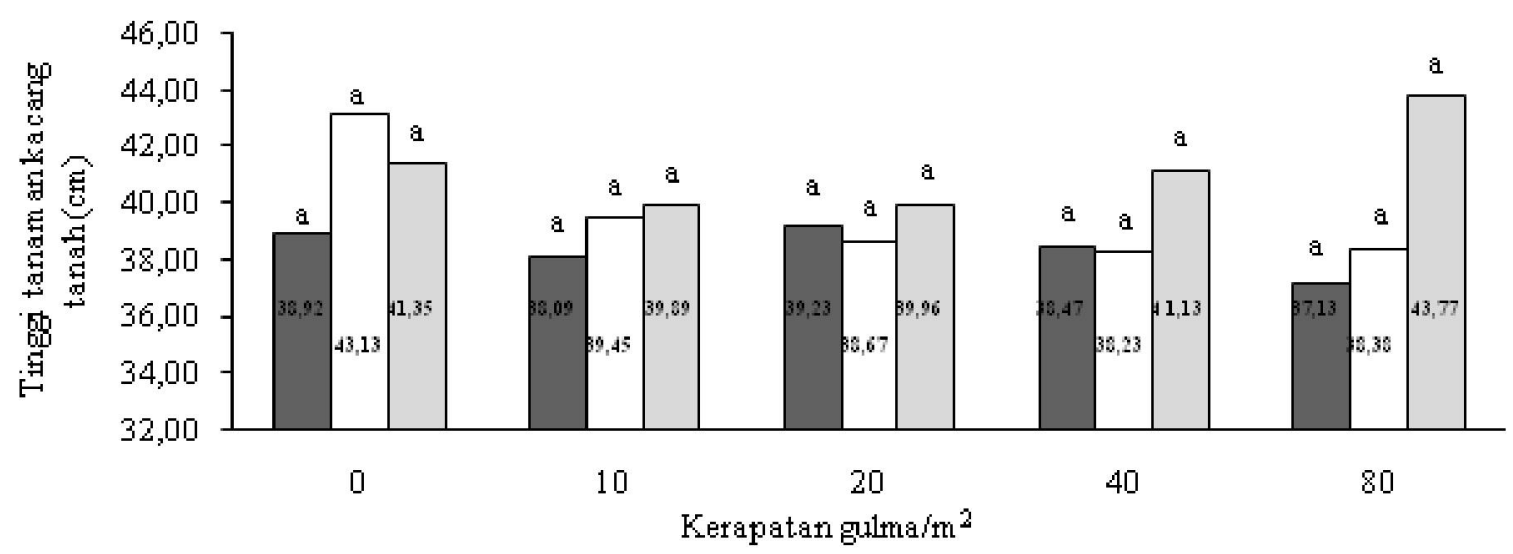

Gambar 3. Pengaruh jenis dan kerapatan gulma terhadap tinggi tanaman kacang tanah (cm). $\square=A$. gangetica, $\square=C$. rotundus, $\square=R$. exaltata, $\mathrm{BNT}(0,05)=8,13$.

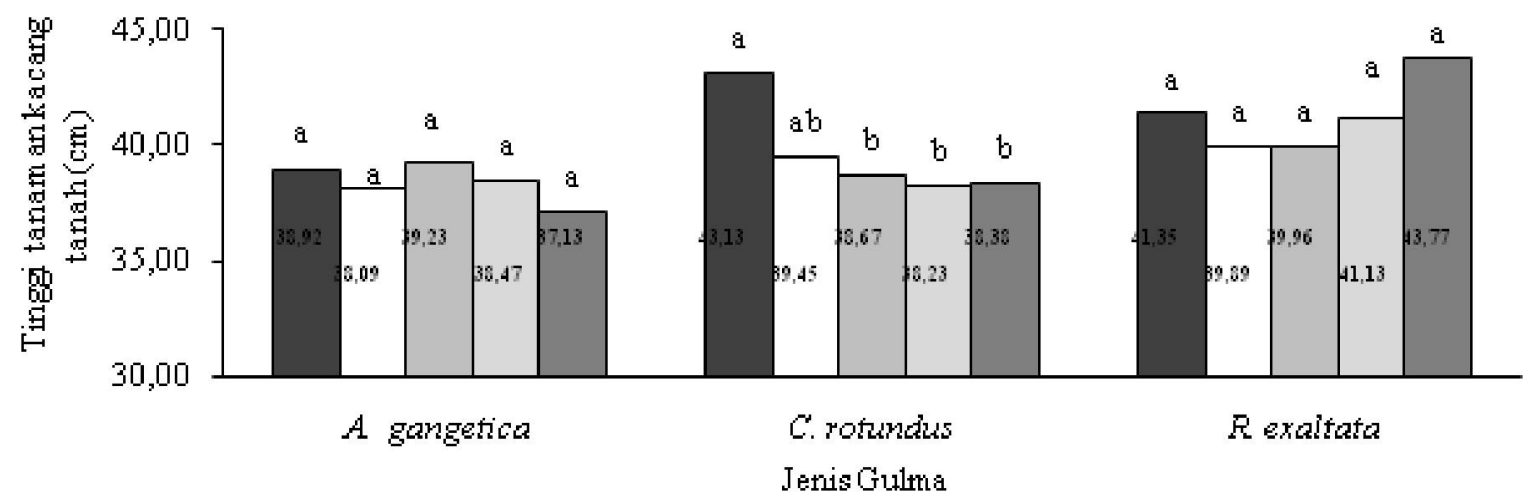

Gambar 4. Pengaruh jenis dan kerapatan gulma terhadap tinggi tanaman kacang tanah. $\square=0$ gulma $/ \mathrm{m}^{2}, \square=10$ gulma $/ \mathrm{m}^{2}, \square=20$ gulma $/ \mathrm{m}^{2}, \square=40$ gulma $/ \mathrm{m}^{2}, \square=80$ gulma $/ \mathrm{m}^{2}$, BNT $(0,05)=3,97$.

akar yang mampu berkembang ke segala arah sehingga menghambat perakaran kacang tanah dalam memperebutkan air dan unsur hara yang tersedia.

Terdapat interaksi antara jenis dan kerapatan gulma dalam mempengaruhi bobot 100 butir. Pada kerapatan 10 sampai 80 gulma $/ \mathrm{m}^{2}$, kacang tanah yang berkompetisi dengan $R$. exaltata memiliki bobot 100 butir lebih rendah daripada $A$. gangetica dan C. rotundus (Gambar 5). Pada perlakuan R. exaltata, bobot 100 butir pada kerapatan 10 sampai 80 gulma $/ \mathrm{m}^{2}$ lebih rendah daripada kontrol. Sebaliknya kacang tanah yang berkompetisi dengan A. gangetica dan C. rotundus memiliki bobot 100 butir yang sama pada semua kerapatan gulma. Pada kerapatan 10 sampai 80 gulma/ $\mathrm{m}^{2}$, kacang tanah yang berkompetisi dengan $R$. exaltata mengakibatkam bobot 100 butir kacang tanah tertekan sebesar $18-23 \%$ (Gambar 6). R. exaltata memiliki tajuk yang lebih tinggi daripada kacang tanah, sehingga kacang tanah ternaungi oleh $R$. exaltata. Menurut Myrna dan Lestari (2010), cahaya merupakan salah satu faktor lingkungan yang mempengaruhi pertumbuhan dan produksi tanaman kacang tanah. Penelitian ini didukung dengan Gardner, dkk. (1991) dalam Myrna dan Lestari (2010), intensitas cahaya akan besar pengaruhnya selama fase vegetatif dan generatif seperti pertumbuhan tinggi tanaman dan pada saat pengisian polong.

Terdapat interaksi antara jenis dan kerapatan gulma dalam mempengaruhi bobot polong kering per petak. Pada kerapatan 10 sampai 80 gulma $/ \mathrm{m}^{2}$, kacang tanah yang berkompetisi dengan $R$. exaltata memiliki bobot polong kering per petak lebih rendah daripada A.gangetica dan C. rotundus. Sebaliknya pada perlakuan A. gangetica dan C. rotundus, bobot polong kering per petak tidak dipengaruhi oleh kerapatan gulma (Gambar 7). Hal ini diduga karena A. gangetica mengalami cekaman (stres) pada saat transplanting bibit sedangkan $C$. rotundus ternaungi oleh tanaman kacang tanah. Menurut Hartman dan Kester (1986) dalam Yahya dan Awilham (2002), tanam pindah dengan bibit mengakibatkan $A$. gangetica mengalami kerusakan 
akar sehingga pertumbuhan $A$. gangetica terhenti untuk sementara dan pertumbuhan akan kembali normal apabila cekaman (stres) hilang. Menurut Titrosoedirdjo, dkk. (1984) dalam Widayat (2002), tanaman kacang tanah mempunyai bentuk morfologis yang membuat gulma $C$. rotundus ternaungi, sehingga pertumbuhan $C$. rotundus terlambat.
Pada perlakuan $R$. exaltata, bobot polong kering per petak pada kerapatan 10 sampai 80 gulma $/ \mathrm{m}^{2}$ lebih rendah daripada kontrol. Sebaliknya kacang tanah yang berkompetisi dengan A. gangetica dan C. rotundus memiliki bobot polong kering per petak yang sama pada semua kerapatan gulma. Pada kerapatan 10 sampai 80 gulma/ $\mathrm{m}^{2}$, kacang tanah yang berkompetisi dengan $R$. exaltata mengakibatkan bobot polong kering per petak

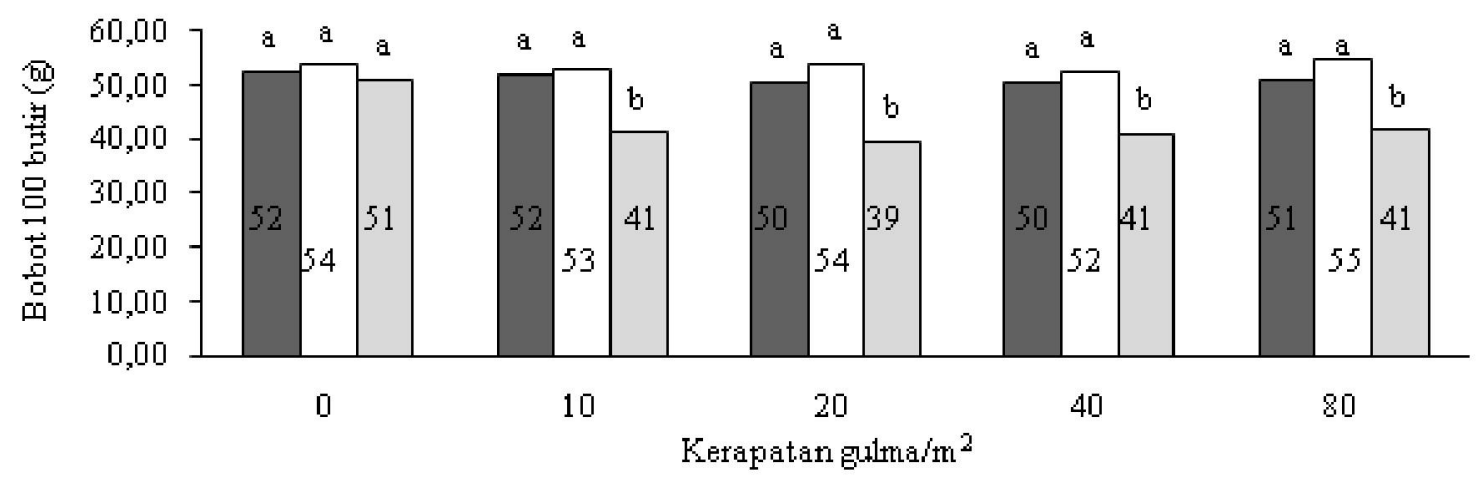

Gambar 5. Pengaruh jenis dan kerapatan gulma terhadap bobot 100 butir. $\square=$ A. gangetica, $\square=C$. rotundus, $\square=R$. exaltata, BNT $(0,05)=4,88$.

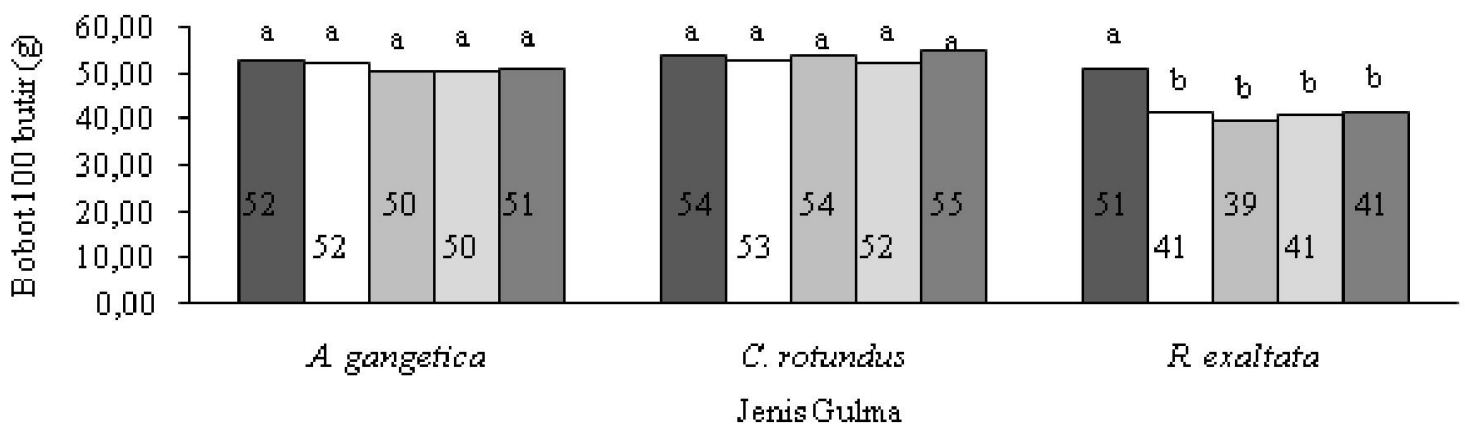

Gambar 6. Pengaruh jenis dan kerapatan gulma terhadap bobot 100 butir. $\square=0$ gulma $/ \mathrm{m}^{2}, \square=10$ gulma $/ \mathrm{m}^{2}, \square$ $=20$ gulma $/ \mathrm{m}^{2}, \square=40$ gulma $/ \mathrm{m}^{2}, \square=80$ gulma $/ \mathrm{m}^{2}$, BNT $(0,05)=5,53$.

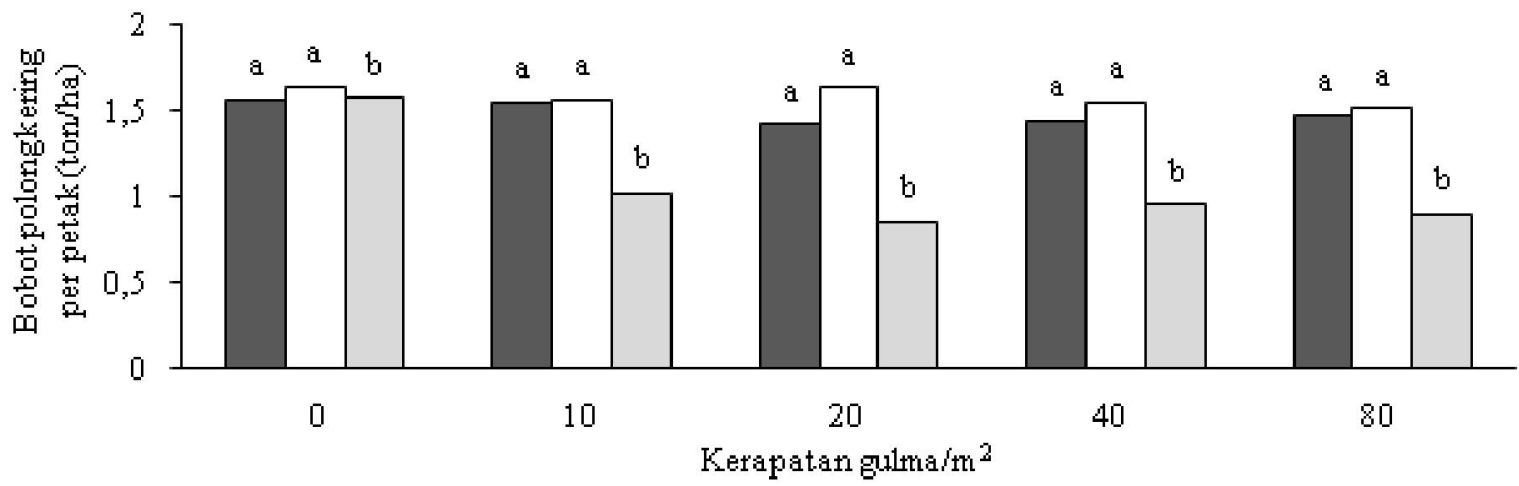

Gambar 7. Pengaruh jenis dan kerapatan gulma terhadap bobot polong kering per petak (Transformasi $\sqrt{ } \sqrt{ }(x+0,5))$. $\square=$ A. gangetica, $\square=C$. rotundus, $\square=R$. exaltata, $\operatorname{BNT}(0,05)=0,32$. 


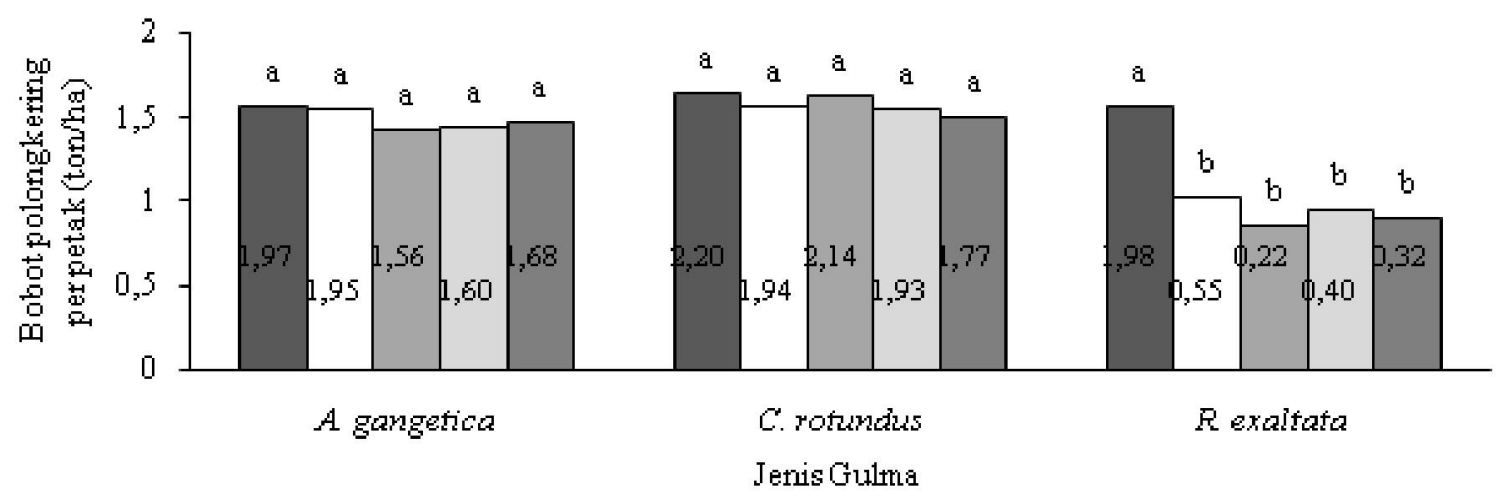

Gambar 8. Pengaruh jenis dan kerapatan gulma terhadap bobot polong kering per petak (Transformasi $\sqrt{ } \sqrt{ }(x+0,5))$. $\square=0$ gulma $/ \mathrm{m}^{2}, \square=10$ gulma $/ \mathrm{m}^{2}, \square=20$ gulma $/ \mathrm{m}^{2}, \square=40$ gulma $/ \mathrm{m}^{2}, \square=80$ gulma $/ \mathrm{m}^{2}$, BNT $(0,05)=0,18$.

tertekan sebesar $72-89 \%$ (Gambar 8). Menurut Hendrival, dkk. (2014), semakin tinggi persen penekanan bobot polong kering per petak maka fotosintat yang dihasilkan oleh polong kacang tanah rendah.

\section{KESIMPULAN}

Dari Penelitian ini dapat disimpulkan bahwa jenis dan kerapatan gulma tidak mempengaruhi pertumbuhan dan produksi kacang tanah dan terdapat interaksi antara jenis dan kerapatan gulma dalam mempengaruhi tinggi tanaman, bobot polong basah, bobot polong kering per petak dan bobot 100 butir kacang tanah.

\section{DAFTAR PUSTAKA}

Arnon, I. 1975. Mineral nutrition of maize int. Potash. Ints. Worbloufen, Bern Switzerland. Pp. 314.

Balai Penelitian Tanaman Kacang dan Umbi. 2013. Kacang Tanah Varietas Hypoma 2. Kalimantan Timur. Samarainda. $23 \mathrm{hlm}$.

Direktorat Budidaya Aneka Kacang dan Umbi. 2013. Prospek Pengembangan Agribisnis Kacang Tanah. Diakses pada tanggal: 22 November 2014.

Hendrival, W. Zurrahmi, dan A. Abdul. 2014. Periode kritis tanaman kedelai terhadap persaingan gulma. J. Floratek. 9: 6-13.

Knezevic, S.Z., S.P. Evans, E.E. Blankenship, R.C.Van Acker, dan J.L. Lindquiest 2002. Critical period for weed control: the concept and data analysis. Weed Science 50: 773-786.

Moenandir, J. 1993. Pengantar Ilmu dan Pengendalian Gulma. PT. Rajawali Press. Jakarta. $143 \mathrm{hlm}$.
Myrna, N. E. F. dan A. P. Lestari. 2010. Peningkatan efisiensi konversi energi matahari pada pertanaman kedelai melalui penanaman jagung dengan jarak tanam berbeda. J. Penelitian Universitas Jambi Seri Sains 12 (2): 49-54.

Pranesti, A., R. Rohlan, dan W. Sriyanto. 2014. Pengaruh tingkat kerapatan teki (Cyperus rotundus L.) terhadap pertumbuhan dan hasil dua habitus wijen ( Sesamum indicum L.). J.Vegetalika 3(4): 119130.

Reeder, R.H., E. Carola, dan T. Matthiew. 1996. Population dynamic aspects of interaction between the weed Rottboellia cochinchinensis (itch grass) and the potential biological control agent Sporisorium ophiuri (bead smut). Prosiding. University Cape Town. South Africa. Pp. 205-211.

Rogomulyo, R. 2005. Pengelolaan Gulma. http:// elisa.ugm.ac.id/files/AT.SOEJONO/ pengelolaan\%gulma.pdf. Diakses pada tanggal: 19 September 2014.

Sembodo, D.R.J. 2010. Gulma dan Pengelolaannya. Graha Ilmu. Yogyakarta. $166 \mathrm{hlm}$.

Suryadi, S. Lilik, dan S. Roedy. 2013. Kajian intersepsi cahaya matahari pada kacang tanah (Arachis hypogaea L.) diantara tanaman melinjo menggunakan jarak tanam berbeda. J. Produksi Tanaman 1 (4): 42- 50.

Widayat, D. 2002. Kemampuan berkompetisi kedelai (Glycine max) kacang tanah (Arachis hypogaea) dan kacang hijau (Vigna radiate) terhadap teki (Cyperus rotundus). Jurnal Bionatura 4 (2): 118 - 128.

Yahya, S. dan M. Awilham. 2002. Kejut tanam pindah cara cabutan pada pembibitan kelapa sawit. J. Bul. Agron 30 (1): 12 - 20. 